\title{
Flere ph.d.-studerende med mere international baggrund - hvad betyder det for ph.d.-vejledningen?
}

Pia Bøgelund, ph.d., adjunkt, Institut for Planlægning, Aalborg Universitet.

\section{Reviewet artikel}

Gennem de senere år er der kommet flere ph.d.-studerende på de danske universiteter samtidig med, at kravene til færdiggørelse og produktivitet er skærpet. En stadig storre andel af de ph.d.-studerende har desuden en international baggrund. Hvad betyder disse tendenser for den enkelte vejleder? Det undersøger denne artikel på baggrund af en interviewundersøgelse udført på Det Teknisk-Naturvidenskabelige Fakultet på Aalborg Universitet. 12 erfarne ph.d.-vejledere på tværs af to forskningsprogrammer er blevet interviewet. For de fleste vejledere betyder de ændrede vilkair, at deres vejledningspraksis er under forandring: De tager mere ansvar for projekternes mål og rammer; de strukturerer mere; de bliver mere bevidste om problemstillinger $i$ mødet mellem kulturer; de fokuserer mere på rekruttering og afvikling, og så inddrager de i højere grad end før andre i deres vejledning. Artiklen diskuterer til sidst forskelle på de to forskningsprogrammer og rejser nogle relevante forskningsspørgsmål om konsekvenser for ph.d.-uddannelsen som sådan.

\section{Vejlederens perspektiv og praksis i nye rammer}

Med Globaliseringsaftalen fra 2006 blev der fra politisk hold afsat betydelige midler til et meroptag af ph.d.-studerende i Danmark. Det blev endvidere aftalt med de danske universiteter, at væksten i særlig grad skulle ske inden for det teknisk-naturvidenskabelige og sundhedsvidenskabelige område (Forsknings- og Innovationsstyrelsen 2011, s. 111). Optaget af ph.d.-studerende på Det Teknisk-Naturvidenskabelige Fakultet på Aalborg Universitet er i overensstemmelse hermed steget markant de senere år. Fra et relativt stabilt optag på ca. 75 ph.d.-studerende pr. år i de første 4 år af det nye årtusinde, er optaget steget til 209 ph.d.-studerende i 2011. Andelen af internationale ph.d.-studerende er endvidere vokset til i dag at udgøre $53 \%$ af de ph.d.studerende, der er tilknyttet Det Teknisk-Naturvidenskabelige Fakultet. De kommer primært fra asiatiske og afrikanske lande, og særligt fra Kina (ph.d.-sekretariatet 2011). Antallet af ph.d.-vejledere har ikke fulgt samme stigningstakt, så vejlednings- 
presset på den enkelte vejleder er steget ${ }^{1}$ både kvalitativt og kvantitativt. Kvalitativt er de kulturelle koder for at begå sig som ph.d.-studerende i Danmark markant anderledes sammenlignet med asiatiske og afrikanske lande, hvilket afføder forskellige forventninger (se fx Carroll \& Appleton, 2007 eller Ryan, 2000). Hertil kommer et øget ledelsesmæssigt og administrativt pres på ph.d.-vejlederne i form af, at ph.d.studerende bliver færdige til tiden. Kvantitativt har vejlederen et øget antal ph.d.studerende, hvoraf mange har behov for en grundlæggende viden om den danske forskningstradition, og ph.d.-vejlederens rolle kommer i spil på en ny måde.

Denne artikel fokuserer på, hvilke udfordringer den nye situation rejser for ph.d.vejledere. Hvordan oplever vejlederne selv de nye vilkår, og hvilke konsekvenser har de for deres vejledningspraksis i dag? Oplever vejlederne, at der er behov for en anden type vejledning i denne situation? Eller giver de nye rammer ikke anledning til en revision af vejlederrollen? Det eksplorative forskningsspørgsmål kan på baggrund af ovenstående formuleres således: Hvilke praksisser og hvilken selvforståelse beskriver vejledere på det teknisk-naturvidenskabelige område på Aalborg Universitet, når de vejleder et større antal ph.d.-studerende med en mere varieret og international baggrund?

Forskningsmæssigt bidrager artiklen til en øget viden om den virkelighed, som ph.d.-vejledere oplever. I litteraturen om vejledning af ph.d.-studerende tages der ofte udgangspunkt i den ph.d.-studerendes behov med intentionen om at indkredse fænomenet 'den gode vejleder' (Lee, 2008; Wichmann-Hansen, Eika \& Mørcke, 2007). I diskussionen af god vejledning bliver mange emner berørt og mange gode råd delt ud til vejledere (se fx Eley \& Jennings, 2005; Taylor \& Beasley, 2005; Delamont, Atkinson \& Parry, 2004; Rugg \& Petre, 2004). I det omfang, det er vejlederes perspektiv, der er i fokus, er det ofte med særlig interesse for deres personlige holdninger og erfaringer med at indgå i vejledningsrelationer (se fx Wichmann-Hansen Eika \& Mørckes litteratursøgning med fokus på publicerede, evidensbaserede studier i: Wichmann-Hansen, Eika \& Mørcke, 2007). I denne artikel tages udgangspunktet i, hvordan vejledere oplever deres profession, og hvilke rammer og vilkår de har at udføre deres gerning i. Dette har ikke så ofte været i fokus for forskningen på områ$\operatorname{det}^{2}$, men det er et nødvendigt element for at kunne forstå og forandre en ph.d.vejledningspraksis.

\footnotetext{
${ }^{1}$ Vejledere kan naturligvis få en ændret forskningsmæssig og undervisningsmæssig forpligtelse, så der bliver plads til at vejlede flere ph.d.-studerende og det samlede pres ikke stiger.

${ }^{2}$ Lee (2008) beskæftiger sig i nogen grad med den professionsrelaterede kontekst for vejledere ligesom Wichmann-Hansen, Eika \& Mørcke, (2007) referer en mindre gruppe studier, hvor vejledningsformer blev sammenlignet på tværs af fag, discipliner, uddannelsesniveauer og/eller landegrænser.
} 


\section{Design, metodemæssige overvejelser og teoretisk forståelsesramme}

Artiklens empiriske materiale udspringer af en interviewundersøgelse blandt ph.d.vejledere på to forskerskoleprogrammer på Det Teknisk-Naturvidenskabelige Fakultet på Aalborg Universitet. ${ }^{3}$ Det ene program ligger i grænsefladen mellem teknologiske og samfundsfaglige fagtraditioner (Program A), mens det andet program er kendetegnet ved klassiske, tekniske discipliner (Program B). Begge forskerskoleprogrammer er kendetegnet ved at have mange og internationale ${ }^{4}$ ph.d.-studerende. Det førstnævnte program har først for nyligt været igennem en omstillingsproces, hvorunder antallet af ph.d.-studerende og tillige andelen af internationale ph.d.-studerende er steget markant. Det har været en omstillingsproces, der er foregået over en meget kort periode på blot nogle få år. Det sidstnævnte program er startet tidligere og har derfor haft en mere glidende omstillingsproces. Valget af disse to programmer giver såvel mulighed for at undersøge en aktuel som en mere veloverstået omstillingsproces.

De pågældende vejledere repræsenterer et bredt udsnit af fagligheder. Vi har udvalgt vejledere fra forskellige forskningsgrupper i de to forskerskoleprogrammer. ${ }^{5}$ Alle vejledere har erfaring med internationale ph.d.-studerende, og de fleste har eller har haft mange ph.d.-studerende. Interviewundersøgelsen er i høj grad en undersøgelse af 'best practice' på området i og med, at de interviewede ph.d.-vejledere primært er fundet blandt de mere erfarne professorer og lektorer. Der er i alt interviewet 12 vejledere, 6 fra hvert program. Der blev interviewet 11 mænd og 1 kvinde.

Der er spurgt ind til vejledernes praksis, den dominerende praksis i deres nærmeste forskningsmiljø, holdninger og forventninger i forhold til ph.d.-studerende samt deres egen opfattelse af vejledningsstil, udfordringer og erfaringer i forhold til det at være vejleder - særligt i forhold til internationale ph.d.-studerende. Forståelsesrammen er inspireret af Kolmos' og Holgaards model for situationsbaseret vejledning (Kolmos \& Holgaard, 2007), og Argyris' og Schöns begreber om 'theory-in-use' og 'espoused theory' (Argyris \& Schön, 1974) og kan opsummeres i følgende figur:

\footnotetext{
${ }^{3}$ Interviewundersøgelsen er del af et projekt finansieret af Aalborg Universitet og SCKK: Kompetenceløft af ph.d. vejlederen i en interkulturel virkelighed. 1-2 af vejledernes internationale ph.d.-studerende er også blevet interviewet, men disse data indgår ikke i denne artikel.

${ }^{4}$ Internationale dækker alle nationaliteter udover danske. På de to programmer er der store grupper af asiater og mellemøstlige ph.d.-studerende, ligesom de sydeuropæiske, østeuropæiske og indiske grupper er forholdsvis store.

${ }^{5}$ På det ene program blev vejlederne udvalgt på baggrund af en samlet liste over vejledere og ph.d.studerende ift. de enkelte forskningsgrupper. På det andet program blev vejledere udvalgt alene på baggrund af velinformerede centrale forskeres udpegning, da en samlet liste ikke eksisterede på dette program.
} 
Vejlederens selvforståelse i forhold til

vejledningsstil, udfordringer og erfaringer

Praksis - hvem gør hvad,

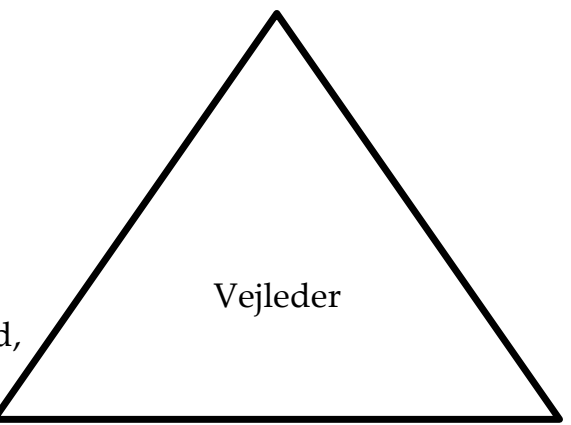

Holdninger og forventninger

hvornår og hvordan?

til den ph.d.-studerende

Kontekst: Flere og mere int. ph.d.-studerende, praksis i nærmeste forskningsmiljø, ledelse

Figur 1: Teoretisk forståelsesramme i forbindelse med interviewundersøgelsen.

\section{Resultater - nye rammer fører til nye refleksioner og skærpet praksis}

Alle 12 vejledere er blevet udfordret i deres vante måde at vejlede på i mødet med flere ph.d.-studerende og mere internationale studerende. Der er forskel på, hvor og hvor meget de er blevet udfordret, og hvordan de tackler det. ${ }^{6}$ Der er naturligvis en personlig dimension i dette, men generelt viser undersøgelsen, at jo flere ph.d.studerende, jo mere fremmedartede kulturer og jo længere tid den pågældende vejleder har været i denne situation, des flere justeringer har den nye virkelighed afstedkommet. Således kan det uddrages fra interviewene, at flere og tillige mere internationale ph.d.-studerende skubber på en udvikling, hvor vejledere oplever øget

- frustration over ændrede arbejdsvilkår og udfordret kvalitet af ph.d.uddannelsen

- behov for at eksplicitere forventninger, strukturere arbejdet og styre projektet

- bevidsthed omkring kulturmøder og besværligheder i den anledning

- behov for at fokusere på rekrutteringen og mulighederne for at stoppe forløb

- behov for at etablere forskningsgruppen som et læringsrum for de studerende

En enkelt vejleder betoner sin erfaring anderledes end de andre, da han selv har været igennem en større kulturel omstillingsproces, men er i øvrigt på linje med de andre i forhold til, hvad det kræver at være vejleder for internationale ph.d.-studerende. I det følgende vil vi gennemgå de forskellige temaer mere detaljeret.

\footnotetext{
${ }^{6}$ To forskere på forskerskoleprogram A med få ph.d.-studerende ( 2 hver) beskrev begge en beskeden forandring af deres vejledningspraksis - hidrørende fra udfordringer med at omstille deres internationale studerende til en dansk forskningspraksis. Forskerne på program B angav generelt, at en ny hverdag havde indfundet sig for et godt stykke tid siden.
} 
Ændrede arbejdsvilkår og udfordrede kvaliteter. På forskerskoleprogram A - med den korte og ret nylige omstillingsproces - har 4 ud af 6 vejledere været frustrerede i processen. ${ }^{7}$ Frustrationen for de 4 udspringer af en stor arbejdsmængde, men skal også ses som en mere generel bekymring for et dalende kvalitetsniveau af ph.d.-uddannelsen og en ændret vejlederfunktion som følge af skærpede ledelsesmæssige krav i en tid med nye typer af studerende:

"Ideen om en ph.d. er under forandring ... alting drejer sig om at skrive publikationer ... før de faktisk bruger tid på at opbygge en forståelse af litteraturen ... og der er et stigende pres fra ledelsen om, at de skal blive fardige til tiden ... [Som vejleder] er du nødt til at træffe en beslutning, om du vil holde dig til de gammeldags vardier eller om du vil blive mere som en projektleder... Som $i$ 'jeg har pengene, dette er hvad vi skal gøre' ... Med de to, der blev fxrdig før jul, fulgte vi en mere traditionel vej. Vi havde altid meget åbne, meget lange diskussioner, hvor vi bare opmuntrede dem ... aldrig kom vi med forslag til hvad deres forskningsspørgsmål skulle være. Vi havde en god, kritisk dialog med dem ... I stigende grad - og da især med internationale studerende-opdager $d u$, at dette ikke kommer til at ske. Ikke på 3 eller 4 år, og måske ikke $i$ det hele taget." (Vejleder 1, A).

Tidspressets indflydelse på kvaliteten af ph.d.-uddannelsen gælder generelt, men er særligt aktuelt $\mathrm{i}$ forhold til de internationale studerende. En anden vejleder på samme program taler også med bekymring om udsigten til at "vi laver to typer af ph.d.studerende" (vejleder 2, A), hvilket i særlig grad har adresse til udfordringerne med at lære kinesiske studerende at arbejde kritisk og problemorienteret. I det hele taget bliver asiatiske og mellemøstlige studerende ofte nævnt som nogle af de studerende, der udfordrer vejlederne omkring kritisk tænkning og selvstændighed. Der er dog undtagelser. En af vejlederne kan således ikke genkende dette billede og siger om sin kinesiske studerende: "Uanset hvad vi foretager os, så bliver det godt ... Hun er kvalificeret, hun er interesseret i ting og på alle måder egnet til dette job" (vejleder 3, A). En anden af vejlederne udtrykker det således: "Den kulturelle dimension er mere et spørgsmålstegn end et udråbstegn" (vejleder 4, B), hvormed han mener, at baggrunden nok giver et fingerpeg, men at det enkelte individ gør udslaget.

Selv om vejlederne på det andet forskerskoleprogram i høj grad deler opfattelsen af, at asiatiske og mellemøstlige studerende er mere autoritetstro, vækker det ikke samme bekymring over kvaliteten. Flere vejledere - både på det ene og det andet program - påpeger, at denne forskel hænger sammen med arten af forskningsområdet. Forskerskoleprogram B fordrer mere teknisk grundviden og har i højere grad virksomhedsrettede, prædefinerede projekter, mens forskerskoleprogram A i højere

${ }^{7}$ Mht. de to sidste se foregående note vedr. program A. 
grad fordrer refleksiv, kritisk socialvidenskabelig sans og har mere individuelle forskningsdagsordener. Det kan også hænge sammen med, at vejlederne på program B har haft en længere tilvænningsperiode og derfor i højere grad har indrettet sig efter de nye forhold. Det vender vi tilbage til senere.

En ændret vejlederrolle i forhold til forventningsafstemning, strukturering og lederskab. Som nævnt ovenfor har nogle af vejlederne en bekymring i forhold til at skulle agere projektansvarlige, når de er vant til og hellere vil være faglige sparringspartnere. Andre er mere parate til at påtage sig et større ansvar for projektets retning, hvis det er det, der efterspørges - dog ikke uden overvejelser:

"Når jeg bliver grebet, skal jeg passe på med at sige, at det her skal vi lave, for det er sjovt. [Jeg skal] måske [hellere] servere det som en mulighed og så træde lidt tilbage. Jeg kan mærke med [den studerende], at han lægger sig meget op ad, hvad jeg siger... Han er meget autoritetstro. Det havde jeg det lidt mærkeligt med $i$ starten ... Det er jo ikke den danske tilgang. ... Han er meget selvstændig, men på en anden måde.... [Den studerende spørger mig] mere: hvad er problemet? Og så går han hen og tackler det.... Det betyder også, at netop fordi, det $i$ den sidste ende er noget jeg bliver stillet til ansvar overfor, så kommer det også til at lægge sig tættere op ad det, jeg laver. Det er jeg mest tryg ved." (Vejleder 5, B).

Vejlederen får her en anden status og mere medejerskab til projektets design. Det er især i forhold til internationale studerende, at vejlederne oplever et pres for at tage mere styring, selv om det øgede antal studerende pr. vejleder og presset om at overholde tidsrammer også bidrager til dette (jf. første store citat). De internationale studerende betyder også, at vejlederne har behov for at blive mere eksplicitte, da der er mange basale ting om den danske arbejds- og forskningskultur, som internationale studerende ikke kender til på forhånd:

"Vores danske ph.d.-studerende er meget forskellige fra vores udenlandske. ... Forskellen er, at danskerne kender kulturen her og er blevet uddannet $i$ et dansk system. Så det er ikke så vanskeligt for dem ... forventningsafstemningen er meget lettere. Forventningsafstemningen med de udenlandske er et større arbejde, hvor du er nødt til at være meget mere eksplicit." (Vejleder 6, A).

7 ud af de 12 vejledere på tværs af forskningsprogrammerne giver udtryk for, at de er blevet mere eller meget mere eksplicitte og styrende. ${ }^{8}$ Både som følge af produktivitets- og effektivitetskrav fra universitetets side af, og som følge af mere autoritets-

\footnotetext{
${ }^{8} 4$ af de sidste 5 var allerede styrende i forhold til emner og deadlines, mens den sidste (med 2 ph.d.studerende) gav udtryk for, at det ikke var ændret, og at han ikke oplevede nævneværdig forskel på internationale og danske ph.d.-studerende.
} 
tro ph.d.-studerende. Det kan være i forhold til at strukturere den enkelte samtale, at bede de studerende om at lave uge- og månedsplaner eller i højere grad end tidligere at "tage styringen", når de oplever, at den ph.d.-studerende har "nogle vilde ideer" (vejleder 7, B). Flere vejledere, især på program A, giver også udtryk for, at de i højere grad skriver sammen med deres ph.d.-studerende. De fleste vejledere er blevet spurgt om det maksimale antal ph.d.-studerende, de vil kunne vejlede. Nogle siger 12 , andre siger 5-6 stykker, og alle er enige om, at 10 ph.d.-studerende er i overkanten. ${ }^{9}$ Det har nogle kvalitetsmæssige omkostninger. Som en af vejlederne udtrykker det: "Hvis man er alene, så er 5-6 stykker topmålet og så skal de være gode"(vejleder $8, \mathrm{~B})$. 'Gode' skal i denne forbindelse forstås som fagligt stærke og selvkørende ph.d.studerende.

Kulturmøder og besværligheder $i$ den anledning. Hvad angår forhold, der ligger ud over det strengt faglige indhold, reagerer vejlederne meget forskelligt i forhold til at håndtere nye kulturers vaner og traditioner. Nogle få vejledere er interesserede i nye kulturer og samtidig meget inviterende i forhold til at fortælle om danske demokratiske og humanistiske idealer, så de får "noget mere med hjem" (vejleder 2, A). Andre vejledere er knapt så nysgerrige og har mere en forventning om, at folk udefra indpasser sig i den eksisterende arbejdskultur (jf. næste store citat). De fleste vejledere sætter pris på, at internationale studerende bidrager med mangfoldighed og andre perspektiver på en velkendt problemstilling samtidigt med, at de erkender, at de ofte vælger en international, fordi "der ikke er nogen dansk ph.d.-studerende at få" (vejleder 9, B), og det er nemmere at sætte en dansker ind i sagerne. Dette gælder dog ikke de 4 vejledere, der selv har international baggrund. ${ }^{10}$ Enkelte kulturmøder giver anledning til, at vejledere pludselig skal til at forholde sig til helt uvante ting:

"Hans hygiejne var ikke særlig god ... jeg fik arrangeret det sådan, at han fik enmandskontor ... de andre havde ikke sagt noget til det, men jeg kunne simpelthen mærke det, når jeg kom ind. ... Det er den svære kommunikation ... Hvis det er fagligt, så er der ingen problemer, men det personlige, det er sværere." (Vejleder 9, B).

Det er særligt de personlige og de religiøse spørgsmål, der kan få nogle vejledere lidt på glatis. Som en anden vejleder siger om det, at en ph.d.-studerende beder fredagsbøn: "Er det noget vi skal [interessere os for], eller skal vi ikke blande os?" (vejleder 5, B), mens en anden vejleder har en usikkerhed i forhold til, om det nu også er reelt, når en ph.d.-studerende "smider kulturkortet" (vejleder 7, B ) - altså begrunder sine

\footnotetext{
${ }^{9}$ En enkelt vejleder ser ikke noget problem i at have 20. Det er dog på den præmis, at alle hans ph.d.studerende har en co-vejleder, og at hans bidrag er at mødes ganske kort hver 2. måned med dem begge to.

${ }^{10}$ Herudover skiller de 4 internationale vejledere sig ikke ud som en særlig gruppe -3 af dem har været ansat her i mange år.
} 
handlinger kulturelt. Der er en vis berøringsangst over for det fremmedartede blandt flere af vejlederne. Generelt er der dog mange divergerende holdninger, forventninger og erfaringer med den kulturelle dimension blandt vejlederne - der er meget lidt konsensus om den kulturelle dimensions betydning.

Rekrutteringen og mulighederne for at stoppe forløb. Det er ikke alle vejledere, der fortæller, at deres vejledningspraksis har forandret sig markant. Det gælder især vejledere på program B. En af vejlederne beskriver sine overvejelser på følgende måde:

"Jeg gør ikke noget andet med de forskellige ph.d.-studerende - jeg tror jeg er blevet mere kynisk af det, jeg har lært. ... [J]eg ansætter kun kinesere, som har taget deres master i Europa, så de er akklimatiserede i forhold til vores kultur. .. Jeg ansætter ikke folk direkte fra Kina... Det giver for meget overheads, at lave kulturtilvænning også. Jeg har jo [provet at springe ud $i$ det ] med den bedste mand på papiret - en kineser - og det var en tung opgave ... Man er mentor for dem $i$ en lang periode, og det kan man så vælge, om man vil bruge sin tid på. Det vil jeg så ikke." (Vejleder 8, B).

Håndteringen af potentielle udfordringer med de internationale ph.d.-studerende sker altså i rekrutteringen og ikke så meget i den egentlige vejledningspraksis. Denne vejleder udtrykker det måske mest eksplicit, men på program B er der et langt større fokus på rekrutteringsopgaven og på mulighederne for at kunne "komme af med folk", når det er "en nitte" (vejleder 7, B). Potentielle ph.d.-studerende bliver ansat som assistenter først, bliver håndplukket via netværk eller opfostret i egne rækker som masterstuderende. Som tidligere nævnt har forskellen til det andet forskerskoleprogram noget med fagområdet at gøre og den generelle arbejdskultur på de to programmer. Virksomhedsperspektivets indflydelse mærkes tydeligt, når man interviewer vejledere på program $\mathrm{B}$ med deraf følgende klarere rammer og mål for den enkelte ph.d.-studerendes arbejde. På den anden side - og som det også fremgår af ovenstående citat - er der en tendens til, at jo flere oplevelser man som vejleder har haft med "tunge" internationale ph.d.-studerende, jo mere bliver man opmærksom på rekrutteringsopgaven og på mulighederne for at afbryde et forløb. Som en af vejlederne på program A udtrykker det: "Det der med at stoppe nogen har jeg været meget tilbageholdende med, men jeg er der nu" (vejleder 6, A).

Inddragelse af hele forskningsgruppen. De fleste af de vejledere, der har udfordringen med mange og internationale ph.d.-studerende tættest inde på livet - dvs. oftest professorer og forskergruppeledere - er i stigende grad begyndt at inddrage hele forskningsgruppen i uddannelsen af de ph.d.-studerende. Dette gælder især vejledere på program B. Flere af dem arbejder i fællesprojekter eller med laboratorieopgaver, så tendensen til at samarbejde er der i forvejen, men ofte er kravet om en større produktion af ph.d.-studerende og et større behov for kulturel oplæring med til at skubbe på denne udvikling. En af de vejledere, der er længst fremme på dette område, fortæller: 
"Som vejleder fär jeg de ph.d.-studerende til at være selvhjulpne og hjælpe hinanden. [De sidder på samme kontor] og der er mentorordning ... Rigtig god feed back... Vi ... forcerer dem igennem at lave en journal sammen med de andre, og det har jeg haft rigtig god erfaring med: ... '[D] laver den tredjedel, den femtedel' ... Så følger de jo processen, og får respekt. De larer alt det praktiske undervejs. ... De bliver inviteret ind på en meget billig hammel ... og så forventer jeg, at de kan slæbe noget igennem senere. ... Jeg holder gruppemøde hver onsdag: noget socialt... nyheder... oplæg... og alle skal komme. Ellers er det sårbart, hvis nogen er væk. ... [A]t de kan gå direkte til andre ... [og] kun gå til vejleder med det vxsentlige, ellers kan man ikke have så høj en produktion af ph.d.-studerende i så god kvalitet. ... Jeg forsøger at få det næste lag i fødekæden til at træde til, for jeg står og skal skaffe projekter og penge." (Vejleder 5, B).

Det er langtfra alle vejledere, der ønsker eller praktiserer en så systematisk tilgang til uddannelsen af ph.d.-studerende, men det er karakteristisk, at tilstedeværelsen af flere og mere internationale ph.d.-studerende skærper kravet om systematik, struktur og uddelegering for alle vejledere. I det følgende vil vi ridse nogle pointer og konklusioner op i forhold til forskningsspørgsmålet.

\section{Ph.d.-uddannelsen og vejlederrollen under markant forandring?}

Dette stykke empiri undersøger hvordan to bestemte kontekstbundne vilkår - antal og type af ph.d.-studerende - øver indflydelse på ph.d.-vejlederes praksis og selvforståelse i en konkret faglig sammenhæng; Det Teknisk-Naturvidenskabelige Fakultet på Aalborg universitet. Som sådan har undersøgelsen størst gyldighed for lignende faglige forskningsmiljøer, der oplever nogle af de samme rammer og vilkår. I og med den eksplorative karakter af undersøgelsen er der endvidere tale om en første indkredsning af tendenser, der med fordel kan følges op af mere uddybende undersøgelser. Omkring data i øvrigt er det værd at bemærke, at de to grupper af forskere (på hhv. program A og B) er blevet interviewet $\mathrm{i}$ to forskellige faser af en omstillingsproces. Det er en styrke i forhold til at få indblik i forståelser og praksisser i to forskellige faser, men der skal samtidig være opmærksomhed på usamtidigheden, når der drages konklusioner. (Olsen \& Pedersen, 1997, s. 190ff).

Undersøgelsen viser, at de nye vilkår giver anledning til en revision af vejledernes selvforståelse som vejledere og deres praksis. Vejlederrollen er blevet tydeligt mere krævende og stiller krav om tilegnelse af nye kompetencer. Forandringerne er særligt iøjnefaldende på program $\mathrm{A}$, hvor den aktuelle frustration på interviewtidspunktet er stor over, at en rolle som faglig kollegial sparringspartner presses mere i retning af en rolle som projektleder. På program B er projektlederrollen i højere grad accepteret - hvilket dog tillige skal ses i lyset af fagområdets øvrige vilkår med virksomhedssamarbejde og store projekter. Der er en mere etableret hverdag på program B med 
de nye vilkår. Rutinerne forbundet med at udvælge og få et større hold af internationale og danske ph.d.-studerende til at fungere som gruppe er mere indarbejdede. For ph.d.-uddannelsen som helhed er det interessant, om undersøgelsens data tegner et mere generelt billede af en udvikling hen imod mere ledelse og styring fra vejledernes side og en ph.d.-forskning mere sammenkoblet med vejlederens forskning. Det har navnlig interesse i forhold til spørgsmålet om, hvor beslutningskompetencen for centrale valg i forskningsprocessen kan eller bør ligge - hos vejleder eller ph.d.-studerende? Og hvad det betyder for den ph.d.-studerendes tilegnelse af pbl-kompetence? En udvikling hen imod en mere styrende rolle for ph.d.-vejlederen med større ansvar for projektets indhold og mere oplæring i kulturelt bundne arbejdsrutiner har også betydning for vejlederens arbejdsvilkår, og dennes muligheder for at overkomme at facilitere et stigende antal ph.d.-studerendes faglige udvikling. Presset er stigende på vejlederrollen.

Også på anden vis giver de nye vilkår anledning til en ændring af vejlederrollen. Det drejer sig her mere direkte om den kulturelle dimension. Som det fremgår af empirien forholder vejlederne sig meget forskelligt til, at internationale ph.d.-studerende medfører nye vaner, værdier og måder at agere i verden på. Det er dog de færreste, der går i dialog og er nysgerrige på markante forskelligheder. Der er flere vejledere, der står famlende over for det fremmedartede eller foretrækker, at internationale ph.d.-studerende indpasser sig i de eksisterende arbejdskulturer. Ser vi på de to forskningsprogrammer, er der ikke belæg for at konkludere, at længere tids eksponering for internationalisering (forskningsprogram B) medfører større kulturel udveksling. Nok større kendskab og flere rutiner omkring håndtering af udfordringer, men åbenheden er ikke større. Det spørgsmål, der rejser sig i denne sammenhæng, er, hvor internationale og åbne vi i virkeligheden er på ph.d.-uddannelsen, når det kommer til stykket? Og hvor meget betyder effektiviseringsbestræbelser og tidspres i denne sammenhæng? Hvilke konsekvenser har det i givet fald for de internationale ph.d.-studerende, der kommer hertil? Det lader sig ikke besvare på det foreliggende grundlag, men det kunne være såvel forskningsmæssigt som uddannelsesmæssigt interessant at vide mere om.

Samlet set viser denne undersøgelse, at der er forandringer undervejs i vejledningen af ph.d.-studerende, der har betydning såvel for kvaliteten af uddannelsen som for den enkelte vejleders arbejdsvilkår. Hvilke konsekvenser, forandringerne har på længere sigt, lader sig ikke umiddelbart bestemme. Det er et åbent spørgsmål.

\footnotetext{
Pia Bøgelund er adjunkt ved Institut for Planlægning på Aalborg Universitet. Hun arbejder med efteruddannelse og kompetenceudvikling af universitetsansatte og forsker $i$ vejledningspraksis og gruppedynamik. Hun er pt. tovholder i projektet Kompetenceløft af ph.d.-vejlederen i en interkulturel virkelighed.
} 


\section{Litteratur}

Argyris, C. \& Schön, D. (1974). Theory in practice: Increasing professional effectiveness. San Francisco: Jossey-Bass Publishers.

Bøgelund, P. \& Kolmos, A. (2013). Ph.d.-vejledning i et akademisk, markedsdrevet og samfundsforandrende perspektiv. Dansk Universitetspædagogisk Tidsskrift, 8(15). Odense: Syddansk Universitetsforlag.

Carroll, J. \& Appleton, J. (2007). Support and guidance for international students: What is good practice? In: E. Jones \& S. Brown: Internationalising Higher Education: Enhancing learning, Teaching and Curriculum.London: Routledge.

Delamont, S. Atkinson, P., \& Parry, O. (2004). Supervising the doctorate. A guide to success. ( $2^{\text {nd }}$ ed.). Maidenhead: The Society for Research into Higher Education and Open University Press.

Eley, A. \& Jennings, R. (2005). Effective postgraduate supervision. Improving the student/supervisor relationship. Maidenhead: Open University Press.

Forsknings- og Innovationsstyrelsen (2011). Evaluering af forskerkarriereveje - håndtering af forskeres karrierer på de danske universiteter. Delrapport 1. Dokumentarisk analyse. København: Forsknings- og Innovationsstyrelsen.

Kolmos, A. \& Holgaard, J. E. (2007). Situationsbaseret projektvejledning. Dansk Universitetspædagogisk Tidsskrift, 3, 54-62.

Lee, A. (2008). How are doctoral students supervised? Concepts of doctoral research supervision. Retrieved from http://epubs.surrey.ac.uk/info_sci/10

Olsen, P. B. \& Pedersen, K. (1997). Problemorienteret projektarbejde - en værkstøjsbog. Frederiksberg: Roskilde Universitetsforlag.

Ph.d.-sekretariatet (2011). Personlig information pr. e-mail. Aalborg Universitet.

Rugg, G. \& Petre, M. (2004). The unwritten rules of PhD research. Maidenhead: Open University Press.

Ryan, J. (2000). A guide to teaching international students. Oxford: Oxford Centre for Staff and Learning Development.

Taylor, S. \& Beasley, N. (2005). A handbook for doctoral supervisors. New York: Routledge.

Wichmann-Hansen, G., Eika, B. \& Mørcke, A. M. (2007). Hvad findes der af litteratur om vejledning? - Litteratursøgning med fokus på publicerede, evidensbaserede studier. Dansk Universitetspædagogisk Tidsskrift, 3, 11-19. 